Studia i Materiały, 2/2016 (22), cz. 2: 237-248

\title{
Wykorzystanie portali randkowych do nawiązywania relacji społecznych
}

\begin{abstract}
Oskar Szumski*, Marek Zborowski**
Rozwój technologii informatycznych i przeniesienie dużej części życia do rzeczywistości wirtualnej spowodowaty popularyzację wykorzystania portali spotecznościowych do nawiazywania m.in. relacji biznesowych, towarzyskich $i$ zwiazanych $z$ hobby. Brakuje jednak badan naukowych skupionych na analizie portali $i$ aplikacji wykorzystywanych przez dorostych $w$ ramach poszukiwania wirtualnych znajomości poprzez portale randkowe $i$ inne serwisy internetowe tej klasy. Niniejsze badanie ma na celu analize wykorzystania portali spotecznościowych $i$ randkowych do nawiazywania specyficznych relacji zwiazanych ze strefa prywatna. Badani zostali wytonieni spośród grupy studentów Uniwersytetu Warszawskiego. Badania potwierdzity zmianę w podejściu do nawiazywania znajomości z wykorzystaniem portali spotecznościowych oraz portali i aplikacji randkowych.
\end{abstract}

Słowa kluczowe: portal społecznościowy, portal randkowy, relacje społeczne.

Nadesłany: 26.11.2016 | Zaakceptowany do druku: 28.12.2016

\section{The use of online dating sites to establish social relations}

Popularity of information technologies and transfer of big part of personal life to virtual reality enabled more frequent use of social networks to establish relationship including business, social and related to hobbies. There can be noticed lack of research focused on the analysis of portals and applications used by adults within the framework of the search for knowledge through virtual dating sites and other Internet services of this class. Goal of presented research is to analyse the use of social network and dating applications to establish relationship specific for personal sphere of life. Research group was identified from within students of Warsaw University. Research proved change in approach to dating portals and applications from the perspective of establishing new relationship.

Keywords: social networking site, dating portal, social relations.

Submitted: 26.11.2016 | Accepted: 28.12.2016

JEL: M150, O330

* Oskar Szumski - dr, Katedra Systemów Informacyjnych Zarządzania, Wydział Zarządzania, Uniwersytet Warszawski.

Adres do korespondencji: Katedra Systemów Informacyjnych Zarządzania, Wydział Zarządzania, Uniwersytet Warszawski, ul. Szturmowa 1/3, 02-678 Warszawa; e-mail: oskar.szumski@uw.edu,pl.

** Marek Zborowski - dr, Katedra Systemów Informacyjnych Zarządzania, Wydział Zarządzania, Uniwersytet Warszawski.

Adres do korespondencji: Katedra Systemów Informacyjnych Zarządzania, Wydział Zarządzania, Uniwersytet Warszawski, ul. Szturmowa 1/3, 02-678 Warszawa; e-mail: marek.zborowski@uw.edu.pl. 


\section{Wprowadzenie}

Technologie informatyczne, a w szczególności technologie mobilne, w tym smartfony, zmieniły wiele aspektów naszego życia, w tym sposobów nawiązywania relacji towarzyskich, biznesowych i romantycznych. Wzrastające znaczenie tej nowej formy komunikacji i relacji jest widoczne od dekady, kiedy to ,tylko kilku badanych Amerykanów miało doświadczenia $\mathrm{z}$ randkami przez Internet, gdy w 2005 roku agencja Pew Research Center po raz pierwszy przeprowadziła badanie, w porównaniu do obecnych $15 \%$ dorosłych obywateli Stanów Zjednoczonych korzystających $\mathrm{z}$ internetowych portali randkowych oraz aplikacji randkowych" (Smith i Anderson, 2016). W ostatnich latach popularność portali randkowych staje się coraz większa jako metoda nawiązywania relacji społecznych. $31 \%$ samotnych dorosłych, poszukujacych partnerów w Stanach Zjednoczonych, wykorzystywała do tego Portali randkowych lub aplikacji wykorzystywanych do randkowania (Duggan i Smith, 2014). Pomimo wzrostu wykorzystania takich wirtualnych narzędzi poszukiwania nowych znajomości, w dalszym ciągu literatura na ten temat jest bardzo ograniczona. Brak również wnikliwych badań naukowych dotyczacych wykorzystania portali randkowych, a także charakterystyki osób korzystających z takich usług internetowych. W Stanach Zjednoczonych ok. 7\% osób, które wykorzystują aplikacje mobilne korzysta ze społecznościowych aplikacji randkowych (Duggan i Smith, 2014). Na rynku europejskim, np. w Austrii, Niemczech i Szwajcarii, 30,8\% użytkowników korzysta ze społecznościowych aplikacji randkowych (SingleboersenVergleich, 2014). W Polsce takie badania nie zostały jeszcze przeprowadzone.

W artykule przeprowadzono analizę wykorzystania ogólnych portali społecznościowych oraz portali randkowych do nawiązywania relacji społecznych z perspektywy użytkowników. Wraz z rozwojem systemów e-biznesu rośnie ich rola w kształtowaniu norm i zachowań społecznych. Powszechnym zjawiskiem jest przenoszenie zachowań ze świata realnego do Internetu. Jedną ze sfer prywatnego życia, którą obją Internet, jest nawiązywanie relacji towarzyskich. Wraz z rozwojem technologicznym były to początkowo czaty lub komunikatory, a wraz z nadejściem Web 2.0 rolę tę przejęły por- tale społecznościowe (Chmielarz i Szumski, 2016a; Szumski, 2008). Dla wielu osób taki sposób nawiązywania relacji stał się naturalną drogą zastępująca nawiązywanie relacji w świecie rzeczywistym

Należy zauważyć, że sieci społecznościowe oferują nowe możliwości w obszarze budowania relacji społecznych, towarzyskich i biznesowych. Na przykładzie badań przeprowadzonych przez Pew Research Center wiadomo, że obecnie sześciu z każdych dziesięciu Amerykanów korzysta z sieci społecznościowych (social networking sites - SNS), takich jak Facebook lub Twitter, i te portale są wykorzystywane do projekcji doświadczeń obecnych i przeszłych dotyczących romantycznych doświadczeń (Duggan i Smith, 2014). Jako definicję portalu społecznościowego możemy przyjać, że jest to „serwis internetowy współtworzony przez społeczność internautów o podobnych zainteresowaniach, który umożliwia kontakt z przyjaciółmi i dzielenie się informacjami, zainteresowaniami” (Stownik języka polskiego PWN, 2016). Portal randkowy to ,system osobistej prezentacji, który umożliwia wyszukiwanie oraz kontaktowanie się $\mathrm{z}$ innymi osobami za pomocą Internetu w celu umawiania spotkania w świecie rzeczywistym, zwykle w celu rozwoju relacji osobistych, romantyczny lub intymnych (Thompson i Hickey, 2010).

Portale randkowe zrewolucjonizowały sposób, w jaki obecnie osoby nawiązują nowe relacje społeczne, zwłaszcza w obszarach intymnych, udostępniając użytkownikom dostęp do bardzo dużej liczby potencjalnych kandydatów do dalszej znajomości, za pośrednictwem jednego kliknięcia w przycisk. Jako rewolucyjne podejście wirtualne portale randkowe, stały się obszarem badawczym dla wielu specjalistów z różnych dziedzin nauki. Rozszerzona dyskusja tej literatury jest poza zakresem niniejszego badania. Zgodnie $\mathrm{z}$ literaturą (m.in. Ritzer, 2014. s. 70 i n.) perspektywa szybkości nawiązywania relacji społecznych zdecydowanie przeważa w przypadku portali randkowych. Odnosząc się do źródeł takich jak (Finkel, Eastwick, Karney, Reis i Sprecher, 2012), czytelnik może zapoznać się z rozbudowanym stadium przyczyn i konsekwencji tej metody randkowania i nawiązywania różnego typu znajomości.

Zaznaczyć należy jednak, że istnieje znacząca różnica pomiędzy portalami 
randkowymi a społecznościowymi aplikacjami randkowymi, jak np. Tinder. Portale randkowe oferują usługi daące dostęp do charakterystyki użytkownika oraz oczekiwaniami co do potencjalnego kandydata, w kontekście połączenia z użytkownikami o podobnej charakterystyce i oczekiwaniach. Użytkownikami są osoby dorosłe zainteresowane nawiązaniem stałej relacji towarzyskiej oraz niemające nic przeciwko ponoszeniu opłat za usługę. Z drugiej strony społecznościowe aplikacje randkowe, jak np. Tinder, nie wymagają opłat oraz działają w pewnym sensie na innych zasadach niż portale randkowe. Między innymi są dostępne dla wszystkich, w tym osób powyżej 13. roku życia, aczkolwiek grupa docelowa ma powyżej 18 lat (Gatter i Hodkinson, 2016). Zgodnie ze statystykami z połowy 2016 roku liczba użytkowników Internetu wynosi już 50,1\% całej populacji (Internet World Stats, 2016), co sprawia, że osoby niekorzystające z Internetu sa w mniejszości. Jest to na pewno zmiana, która była oczekiwana, jednak jej wpływ będzie można ocenić dopiero w dłuższej perspektywie.

\section{Metoda badawcza}

Z uwagi na ograniczony dostęp do badań w tym obszarze zarówno w literaturze polskiej, jak i zagranicznej autorzy wykorzystali metodę korelacyjną ze standardową próbą badawczą. Z uwagi na brak dedykowanej metody, autorzy zastosowali podejście własne, składające się z następujących etapów:

- analiza ogólnych portali społecznościowych pod kątem funkcjonalności umożliwiających nawiązywanie relacji towarzyskich,

- analiza portali randkowych pod kątem funkcjonalności umożliwiających nawiązywanie relacji towarzyskich,

- uruchomienie badania pilotowego na grupie 6 osób, w celu

- doprecyzowania przydatności portali randkowych do nawiązywania relacji towarzyskich,

- określenia listy serwisów, które należy wziąć pod uwagę w badaniu,

- doprecyzowania kryteriów oceny jakości serwisu randkowego,

- określenia wpływu odbioru społecznego na korzystanie z portali randkowych,
- weryfikacja merytoryczna oraz techniczna ankiety,

- publikacja ankiety na witrynie Wydziału Zarządzania UW,

- przeprowadzenie ankiety wśród studentów,

- analiza uzyskanych wyników oraz ocena merytoryczna,

- sformułowanie wniosków o aktualnym oraz przyszłym wykorzystaniu portali społecznościowych w celu nawiązywania relacji towarzyskich.

Badanie przeprowadzono w dniach od 30 maja do 8 czerwca 2016 roku w grupie studentów I i III roku studiów stacjonarnych Wydziału Zarządzania Uniwersytetu Warszawskiego. Grupa badawcza została wybrana poprzez dobór wygodny. Z uwagi na poczucie prywatności i zwiększenie prawdopodobieństwa uzyskania prawdziwych odpowiedzi do badania nie włączono metryczki, aby nie było możliwości zidentyfikowania uczestników badania. Ogółem w badaniu wzięło udział 109 osób, 58 osoby z I roku oraz 51 z III roku. Pełnych odpowiedzi udzieliły 83 osoby, co stanowi ponad $73 \%$ odpowiedzi.

$\mathrm{Z}$ uwagi na to, że studenci należą do osób powszechnie i często korzystających $\mathrm{z}$ najnowszych technologii, na podstawie ich zachowań możliwe jest przeanalizowanie potencjalnych kierunków rozwoju wykorzystania serwisów społecznościowych. W szczególności nastawienie studentów na nawiązywanie znajomości towarzyskich jest pomocne w określeniu, jak prezentują się aktualne sposoby wykorzystania portali randkowych.

\section{Analiza i dyskusja wyników}

Badane osoby odpowiadały na 22 pytania, podzielone na dwie grupy:

- 5 pytań dotyczących sposobów korzystania z ogólnych portali społecznościowych,

- 17 pytań dotyczących sposobów korzystania z portali randkowych.

W artykule przyjęto podział portali randkowych na następujące kategorie: ogólnego przeznaczenia i profilowane (dla singli lub szybkie randki), wymagające autoryzacji i jej niewymagające, płatne i darmowe. Dla pierwszej grupy pytań pojawiły się odpowiedzi wszystkich badanych osób, druga grupa zawierała pytania fakultatywne. Rysunek 1 przedstawia logowania do portali społecznościowych w ciągu ostatnich 30 dni. Przy- 
Rysunek 1. Logowanie do portali społecznościowych w ciągu ostatnich 30 dni

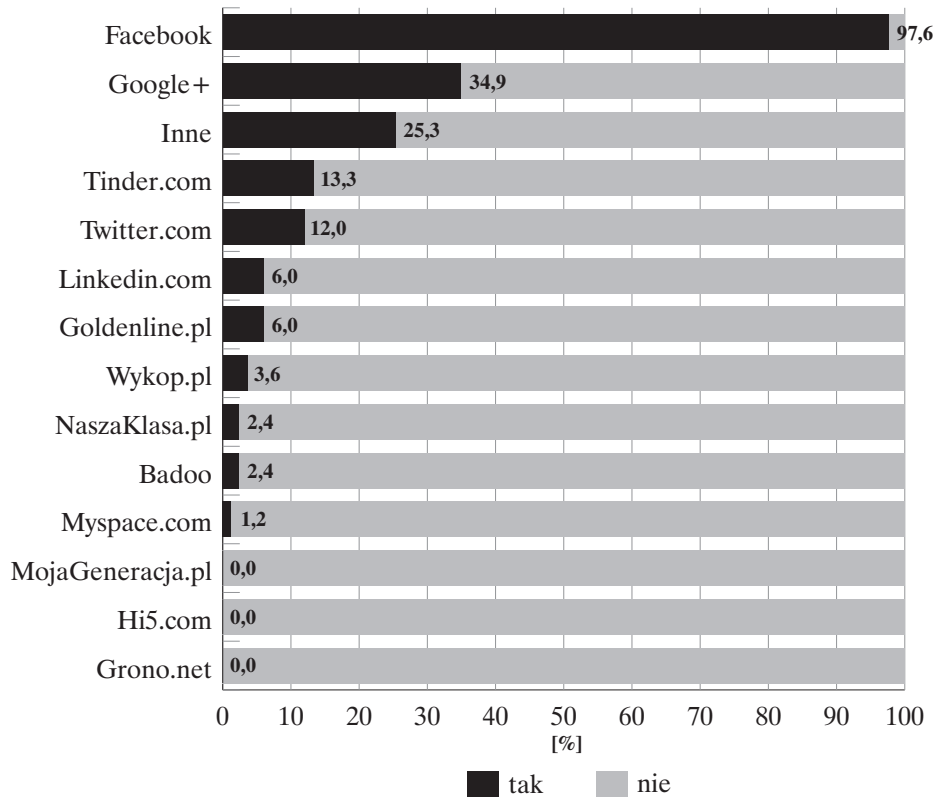

Źródło: opracowanie własne.

jęto założenie, iż osoby aktywnie korzystające z serwisu logują się do niego minimum raz w miesiącu. Wśród studentów dominującą pozycję ma Facebook (ponad $97 \%$ osób). Jest to ogólnoświatowy trend (Greenwood, Perrin i Duggan, 2016), obserwowany w obszarze wykorzystania portali społecznościowych. Nastepne w kolejności są Google + (34,9\%), Tinder $(13,3 \%)$, oraz Twitter $(12,0 \%)$. Dość duża liczba studentów korzysta $\mathrm{z}$ innych portali $(25,3 \%)$, co warte jest przeanalizowania w przyszłości.

Na rysunku 2 przedstawiono istotną kwestię z perspektywy opracowania, czyli jakie są metody wykorzystywania portali społecznościowe przez badane osoby. Prawie 75\% osób wykorzystuje portale społecznościowe do nawiązywania relacji towarzyskich. Ponad $25 \%$ osób nawiązuje relacje biznesowe (profesjonalne, zarobkowe), korzystajac $\mathrm{z}$ portali społecznościowych. Jest to interesujące $\mathrm{z}$ punktu widzenia grupy badawczej, jaka stanowia studenci, gdyż badanie było prowadzone wśród studentów studiów dziennych, co wskazuje również na umacnianie się sposobów szukania pracy, np. na zlecenie, poprzez portale społecznościowe. Dla tej części badanych portal społecznościowy stanowi istotny, jeśli nie jeden z głównych, element ich życia.
Rysunek 2. Wykorzystanie portali społecznościowych do nawiązywania relacji towarzyskich i biznesowych

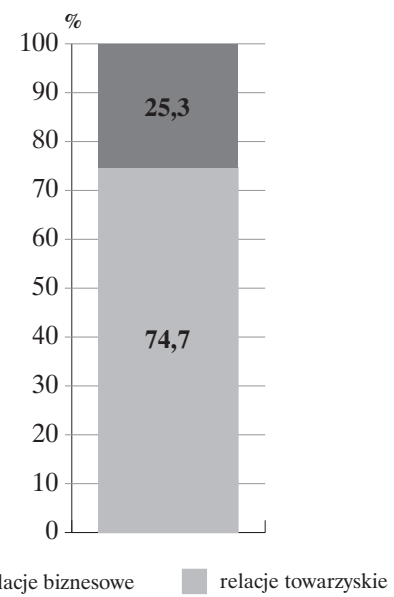

Źródło: opracowanie własne.

Jeżeli chodzi o nawiązywanie relacji towarzyskich oprócz ogólnych portali społecznościowych, równie istotne jest wykorzystywanie dedykowanych portali randkowych i mobilnych aplikacji randkowych. Dla lepszego zobrazowania nawiązywania relacji zestawiono wykorzystanie portali 
Rysunek 3. Wykorzystanie portali społecznościowych do nawiązywania relacji związanych z Twoim hobby oraz portali randkowych

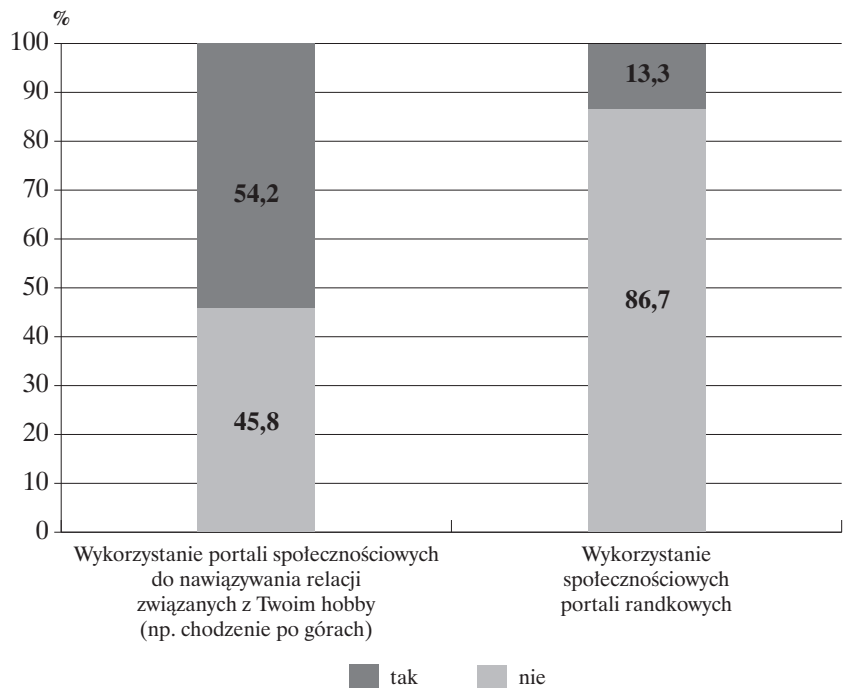

Źródło: opracowanie własne.

społecznościowych w odniesieniu do hobby edarling.pl 7,8\%; pozostałe portale stano(wspólnego spędzania czasu) oraz wykorzy- wią wartość marginalną z wynikami $0 \%$ stanie portali randkowych (rysunek 3). (rysunek 4). Tinder występuje we wszyst-

Wśród portali randkowych największą kich możliwych odpowiedziach kategopopularnością cieszy się Tinder $(40,8 \%)$ rii w odniesieniu do portali randkowych. oraz Sympatia.pl (25\%), randkologia. Jedną z możliwych przyczyn tej sytuacji jest pl 9,2\%, swatka.pl 8,8\%, buziak.pl 8,5\%, brak wykorzystania przez badane osoby

Rysunek 4. Logowanie do portali randkowych w ciągu ostatnich 30 dni

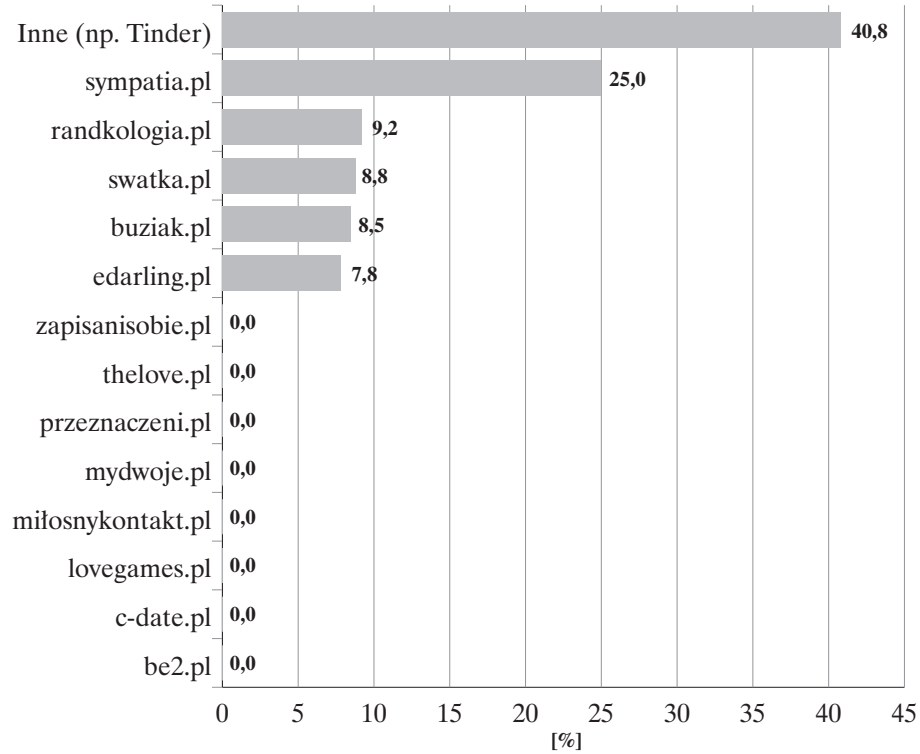

Źródło: opracowanie własne.

Wydział Zarządzania UW DOI 10.7172/1733-9758.2016.22.19 
rozbudowanych funkcjonalności portali i skupienie się na prostych rozwiązaniach dających najszybszy efekt. Jest to spostrzeżenie warte dalszych badań.

Jednym z pytań dotyczących bezpieczeństwa korzystania z portali randkowych było pytanie o korzystanie z portali ,bez logowania". Z uwagi na brak jakiejkolwiek weryfikacji użytkowników na takim portalu występuje duży stopień prawdopodobieństwa spotkania z niechcianymi zachowaniami. $\mathrm{Z}$ takich portali korzysta tylko około $9 \%$ badanych (pomimo braku opłat na rzecz portalu), co oznacza, że świadomość występowania potencjalnych zagrożeń jest dość wysoka (rysunek 5).

Rysunek 5. Wykorzystanie społecznościowych portali randkowych „bez logowania”

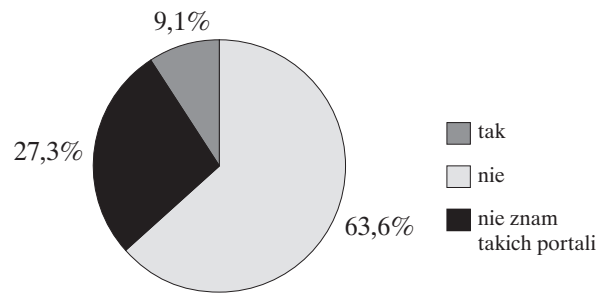

Źródło: opracowanie własne.

Wśród portali typu „szybkie randki” największą popularnością cieszył się Tinder (ponad 27\%), następnie miłosnykontakt. pl (ponad 19\%), zarandkowani.pl (ponad $18 \%$ ) oraz inne (np. Badoo) (ponad 16\%) (rysunek 6). Biorąc pod uwagę udział aplikacji globalnych (ponad 44\%), można zauważyć znaczne zainteresowanie wśród badanych portalami globalnymi, które są rozwiązaniami bardziej dojrzałymi, dla których funkcjonuje profesjonalne wsparcie użytkownika. Portale globalne umożliwiają poznawanie osób z całego świata, bez względu na miejsce pobytu. Są to też serwisy bardziej dojrzałe niż rodzime, polskie portale. Idzie za tym bardziej wiarygodne wykorzystanie i szersza grupa użytkowników niż w przypadku polskich serwisów.

Analogicznie jak w przypadku poprzednich pytań w kategorii portali dla singli użytkownicy wskazali Tinder jako najbardziej popularny (rysunek 7).

Na rysunku 8 przedstawiono cele korzystania z portali randkowych. Prawie $39 \%$ użytkowników szuka poważnej relacji (przyjaźń prawie 22\%, miłości prawie 17\%), natomiast $28 \%$ badanych szuka przygodnych relacji (motywacja seksualna, luźna znajomość). Motywacja użytkowników jest jedna z kluczowych kwestii odnośnie do wyboru samego portalu oraz sposobu jego wykorzystania. W przyszłych badaniach należy połączyć motywację badanych z rodzajami portali, z których korzystają. Zaskakujące było wskazanie szukania sponsoringu przez ponad 4\% badanych. Może to wskazywać na problemy ze źródłami finansowania studiowania.

Jedną z kluczowych kwestii dotyczących istnienia portali społecznościowych, a w szczególności portali randkowych są treści tworzone przez użytkowników (w przypadku portali randkowych są to profile użytkowników). Ponad $81 \%$ badanych publikuje prawdziwe dane (rysunek 9).

Rysunek 6. Logowanie do serwisów społecznościowych typu szybkie randki w ciągu ostatnich 30 dni

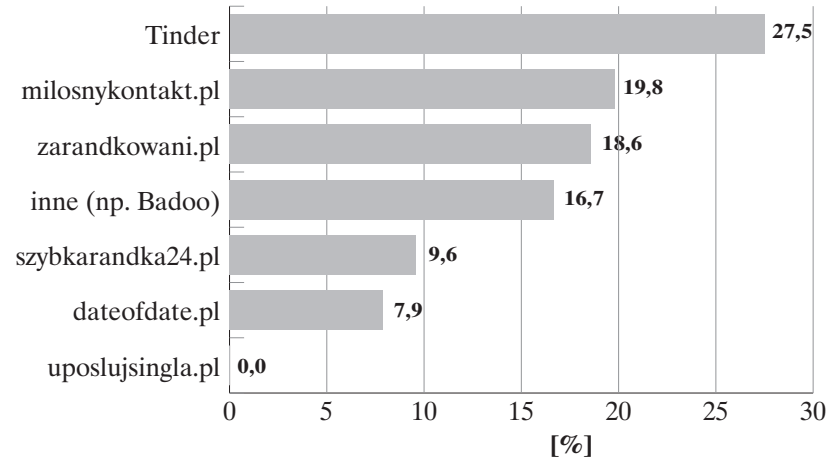

Źródło: opracowanie własne. 
Rysunek 7. Logowanie do serwisów społecznościowych przeznaczonych dla singli w ciągu ostatnich $30 \mathrm{dni}$

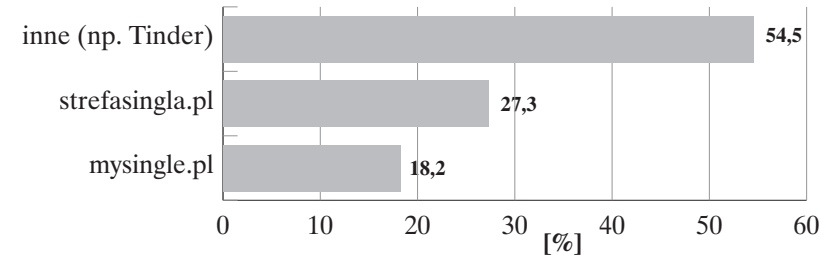

Źródło: opracowanie własne.

Rysunek 8. Cele korzystania z serwisów randkowych

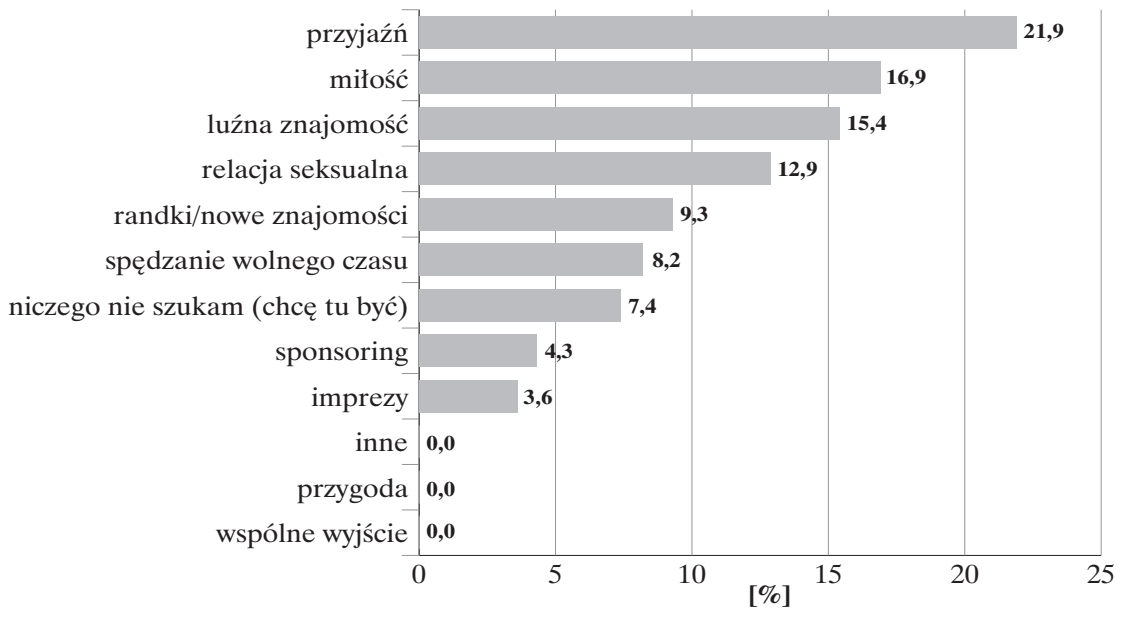

Źródło: opracowanie własne.

Rysunek 9. Czy przy wprowadzaniu danych $w$ profilu $w$ serwisie randkowym podawane są prawdziwe dane?

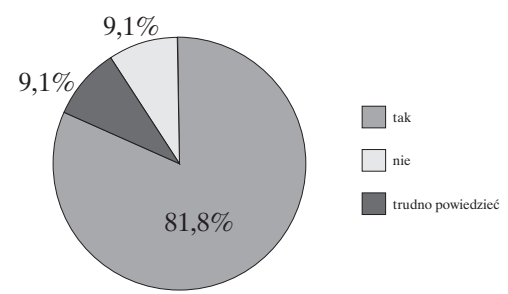

Żródło: opracowanie własne.

W odniesieniu do finansowania portali to badane osoby w większości korzystają z darmowych serwisów (ponad 90\%) (rysunek 10). Stąd głównymi źródłami przychodów dla portali randkowych są reklamy oraz użytkownicy premium - korzystający z dodatkowych funkcjonalności (Wesley, 2010).
Bardzo zbliżone odpowiedzi do poprzedniego pytania uzyskano w odniesieniu do potencjalnych miesięcznych opłat za korzystanie z portalu randkowego. Ponad $81 \%$ badanych nie jest skłonna płacić za korzystanie z serwisu (rysunek 11).

W artykule dla portali randkowych zdefiniowano najważniejsze funkcjonalności, do których zaliczaja się: dodanie do „ulubionych", napisanie wiadomości, wyróżnienie użytkownika, wysłanie ,wirtualnej” karty do flirtu towarzyskiego, wysłanie emotikona, wystapienie w roli eksperta (porady dla innych). Popularność usług typu Tinder, czyli mających proste funkcjonalności, wynika również ze sposobu wykorzystania funkcjonalności portali randkowych. Użytkownicy głównie wysyłają wiadomości oraz wyszukują osoby wg prostych kryteriów (ponad 82\%) (rysunek 12). Może to wskazywać na szersze zjawisko w odniesieniu do portali społecznościowych, czyli potrzebę 
Rysunek 10. Korzystanie z darmowych i płatnych portali randkowych

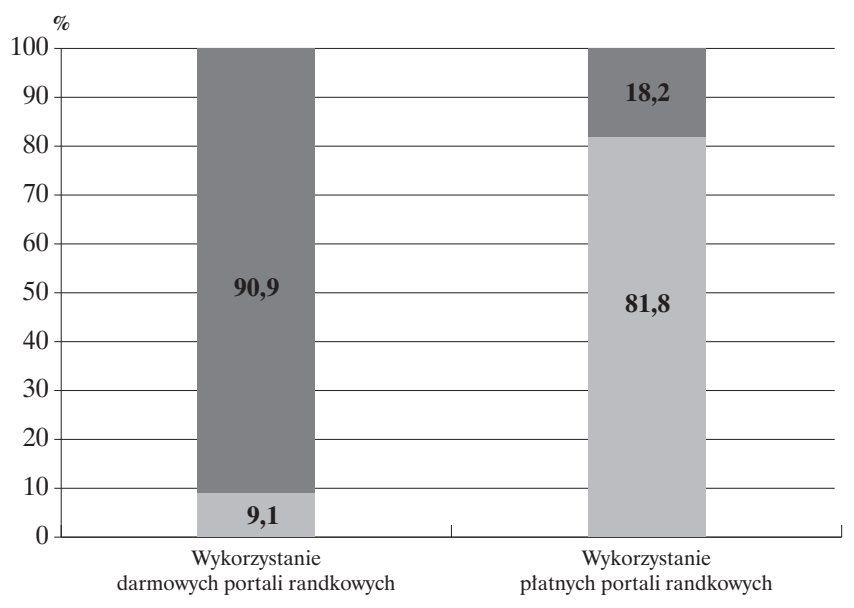

tak nie

Źródło: opracowanie własne.

Rysunek 11. Kwoty potencjalnych miesięcznych opłat za korzystanie z portalu randkowego

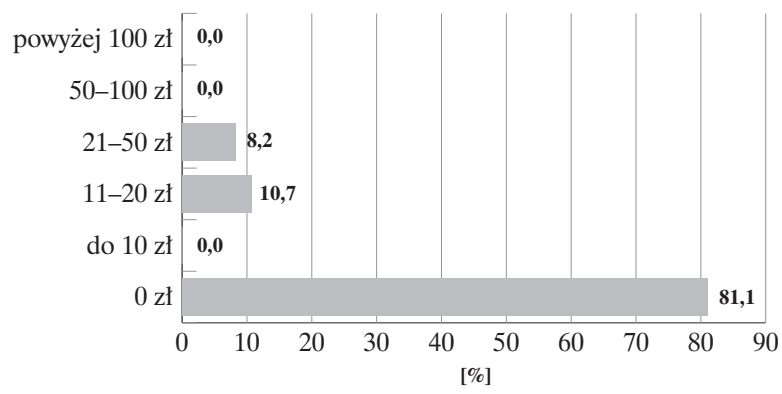

Źródło: opracowanie własne.

Rysunek 12. Wykorzystanie funkcjonalności na portalu randkowym

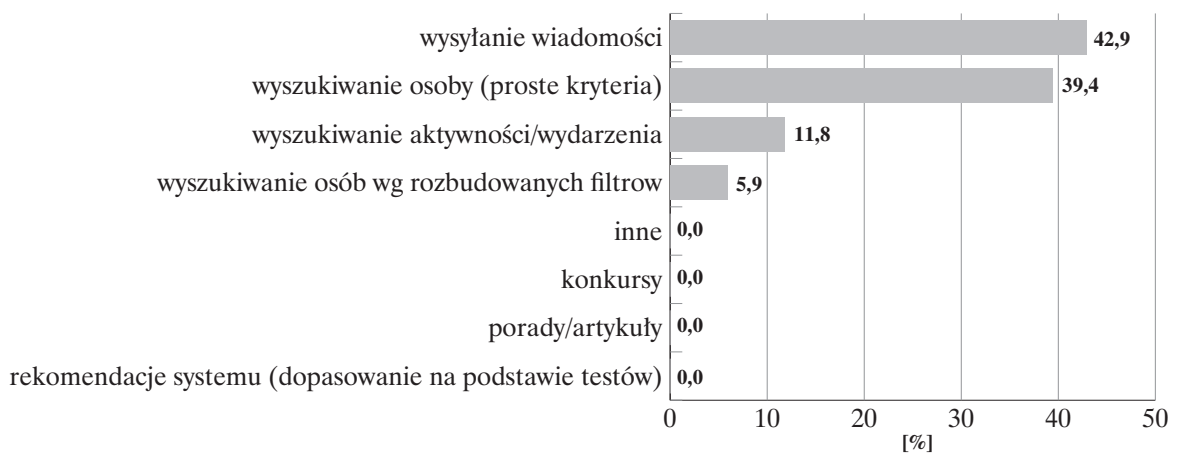

Źródło: opracowanie własne 
Rysunek 13. Sposoby nawiązywania relacji z drugą osobą na portalu randkowym

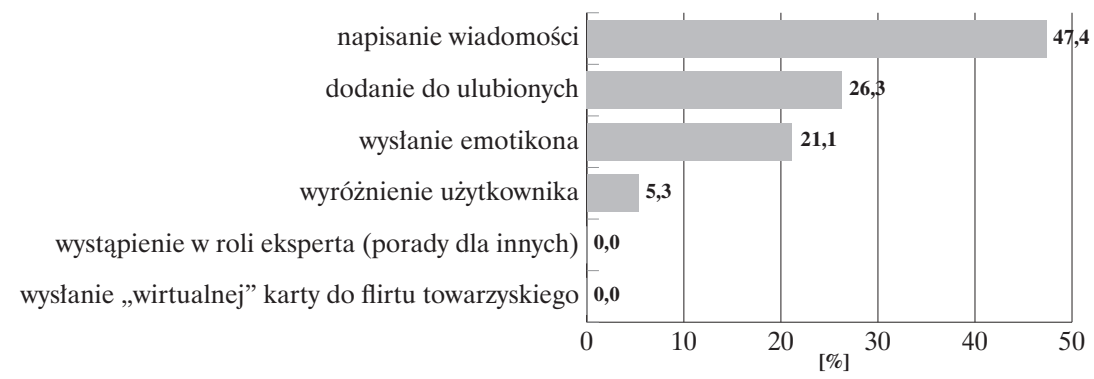

Źródło: opracowanie własne.

korzystania na urządzeniach mobilnych, obsługiwanych przez interfejs dotykowy, gdzie samo działanie serwisu jest bardziej istotne niż mnogość funkcjonalności.

Jeżeli chodzi o sposoby nawiązywania relacji z innymi osobami na portalach randkowych, największą popularnością cieszy się wysyłanie wiadomości (ponad 47\%), dodawanie do ulubionych (ponad 26\%) oraz wysłanie emotikona (ponad 21\%) (rysunek 13). Można te odpowiedzi potraktować jako rekomendację dla twórców takich portali, wskazującą na ograniczoną rolę dodatkowych funkcjonalności.

Zaskakujące były odpowiedzi odnośnie do korzystania z wydarzeń organizowanych przez portale randkowe. Należy jednak rozróżnić wydarzenie z deklarowaną gotowością do uczestnictwa od ogłoszenia o potencjalnej imprezie, na którą zainteresowani mogą udać się anonimowo.

Ponad $90 \%$ badanych nie korzysta z wydarzeń organizowanych na portalach (rysunek 14). Albo więc badani realizuja potrzebę uczestnictwa w wydarzeniach czy imprezach poprzez inne portale, albo obawiają się, że informacja o uczestnictwie zostanie opublikowana w ich głównym profilu na portalu społecznościowym
Rysunek 14. Udział w wydarzeniach organizowanych przez portal randkowy

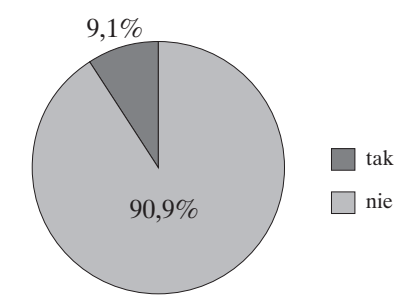

Źródło: opracowanie własne.

(np. na Facebooku). W tym artykule kwestia motywacji uczestnictwa bądź braku uczestnictwa w wydarzeniach i imprezach organizowanych przez portale nie została zinwestygowana i jest obszarem do dalszych badań.

Większe zainteresowanie badani wykazali imprezami promowanymi przez portale randkowe. $\mathrm{Z}$ wyników badania można jednak wysnuć wniosek, że nawet imprezy promowane przez portale nie cieszą się popularnością pośród użytkowników serwisów. W tym przypadku nie korzysta z takich wydarzeń ponad $63 \%$ badanych, natomiast zainteresowanie szybkimi randkami lub imprezami tanecznymi wykazuje

Rysunek 15. Udział w imprezach promowanych przez portal randkowy

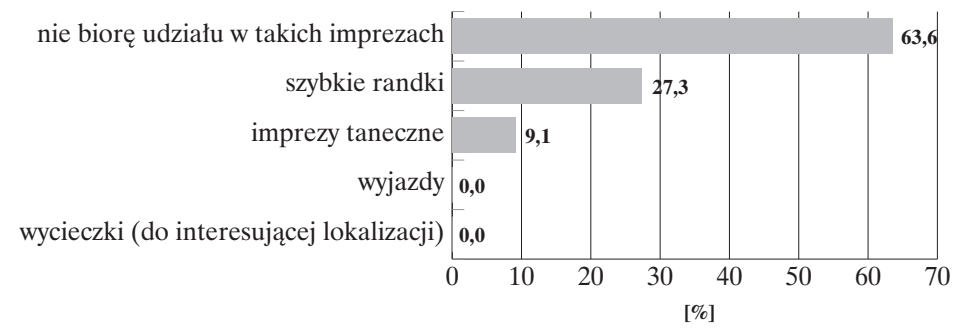

Źródło: opracowanie własne.

Wydział Zarządzania UW ～DOI 10.7172/1733-9758.2016.22.19 
Rysunek 16. Wykorzystanie portali randkowych przez najbliższe osoby oraz odbiór społeczny tego zjawiska

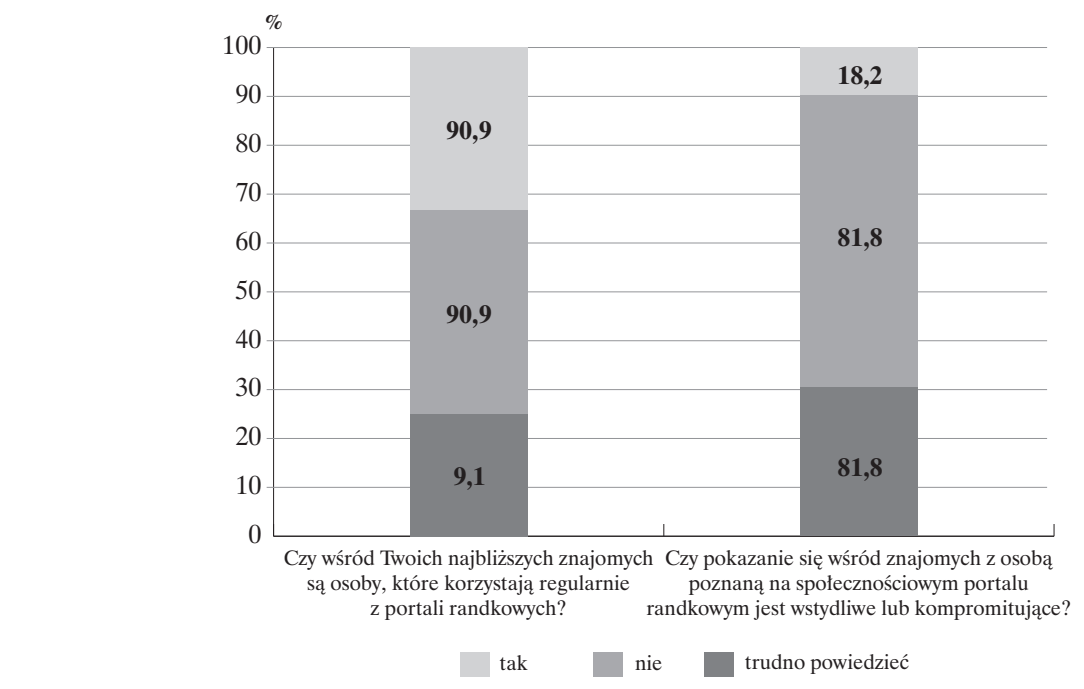

Źródło: opracowanie własne.

odpowiednio ponad $27 \%$ oraz ponad $9 \%$ badanych (rysunek 15).

Przeniesienie życia do wirtualnej rzeczywistości (Chmielarz i Szumski, 2016b) oraz popularyzacja portali społecznościowych i randkowych spowodowały, że stygmatyzacja korzystania $\mathrm{z}$ tego typu usług i serwisów przestała mieć znaczenie wśród dorosłych użytkowników internetu. Dla badanych osób w dalszym ciagu istotna kwestią jest odbiór społeczny ich zachowań w Internecie. Ponad 33\% badanych zna osoby korzystające z portali randkowych, jak również dla prawie $60 \%$ badanych nie stanowi problemu pokazanie się wśród znajomych $\mathrm{z}$ osoba poznana na portalu randkowym (rysunek 16). Tylko niecałe $10 \%$ twierdzi, że pokazanie się z osobą poznaną przez Internet może być odebrane negatywnie przez otoczenie, a co za tym idzie może towarzyszyć mu poczucie wstydu i kompromitacji. Niewiele ponad $30 \%$ badanych nie miało sprecyzowanej opinii $\mathrm{w}$ tej kwestii.

Dla ponad $68 \%$ badanych główne cele to znalezienie przyjaciół lub możliwość spędzania czasu w towarzystwie (np. wyjazd, spacer). Dla ponad $31 \%$ badanych celem jest znalezienie miłości lub spotkanie intymne (rysunek 17). Jest to wskazanie kierunku rozwoju portali randkowych, które z perspektywy większości osób powinny być miejscem bezpiecznym, ze zweryfikowanymi użytkownikami, w którym można umieszczać swoje dane w sposób gwarantujący prywatność.

Doświadczenia osób korzystających $\mathrm{z}$ portali randkowych wskazują na brak występowania serwisów spełniających ich wymagania. Tylko ponad $12 \%$ badanych poleciłoby korzystanie $\mathrm{z}$ takich portali.

Rysunek 17. Cele korzystania z portali randkowych

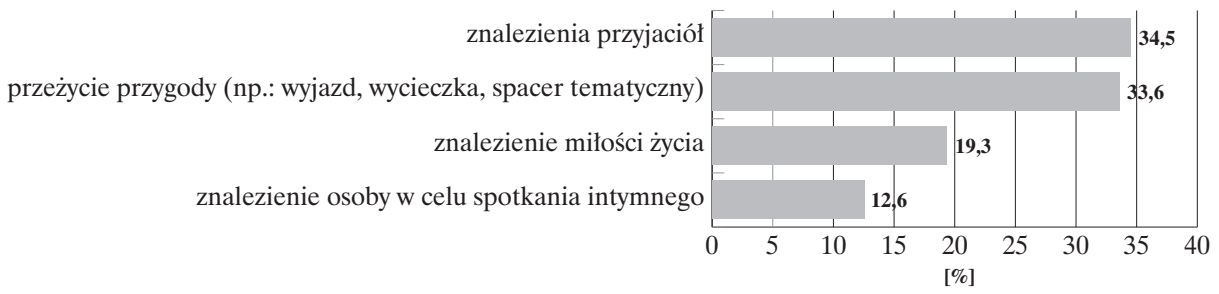

Źródło: opracowanie własne. 
Rysunek 18. Polecanie znajomym korzystania z portali randkowych

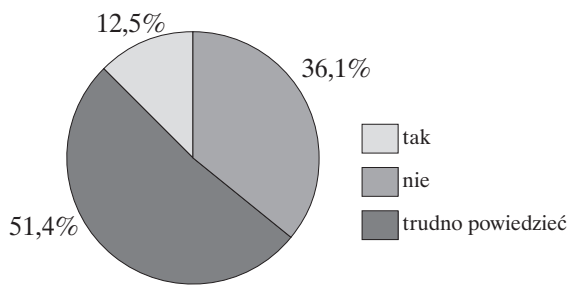

Źródło: opracowanie własne.

\section{Podsumowanie}

$\mathrm{Na}$ podstawie uzyskanych wyników można sformułować następujące wnioski: - prawie wszyscy badani użytkownicy korzystaja z portali społecznościowych (ponad 97\% korzysta z Facebooka), co potwierdza ogólnoświatowy trend. $\mathrm{Z}$ samodzielnych portali randkowych korzysta zdecydowana mniejszość. Jest to negatywne zjawisko dla przedsiębiorstw prowadzących takie portale randkowe lokalnie, ponieważ prawdopodobnie użytkownicy realizuja potrzebe zawierania znajomości poprzez portale ogólne lub w oparciu o portale dedykowane (np. Tinder),

- badani korzystają przede wszystkim $\mathrm{z}$ aplikacji Tinder, co może świadczyć o zmianie potrzeb użytkowników na aplikacje prostsze w obsłudze oraz dające możliwość korzystania z sieci globalnej,

- wg badanych następuje unifikacja portali randkowych, zanikają cechy rozróżniające portal randkowy na rzecz prostszych społecznościowych aplikacji randkowych. Przykładem jest występowanie Tindera we wpisywanych odpowiedziach dla wartości inne w pytaniach o rodzaje serwisów randkowych,

- w dalszym ciagu brak jest portali randkowych zaspokajających potrzeby większości użytkowników (znalezienie przyjaciół lub możliwość spędzania czasu w towarzystwie),

- popularyzacja portali społecznościowych i randkowych spowodowała, że stygmatyzacja korzystania z tego typu usług i serwisów przestała mieć znaczenie wśród dorosłych użytkowników internetu. Dla większości badanych możliwość pokazania się z osobą poznaną online przez portal lub aplikację randkową nie stanowi problemu,

- widoczna jest dominacja portali globalnych (np. Tinder), stąd tworzenie rozwiązań lokalnych w długim okresie może być nieopłacalne,

- z uwagi na funkcjonalności, najcześściej wykorzystywane przez użytkowników typu (wysyłanie krótkich wiadomości, polubienia), rozbudowane funkcjonalnie portale randkowe nie spełniają oczekiwań badanych i często są na niskim poziomie. Można zatem przedstawić rekomendację ograniczenia stopnia zaawansowania takiego serwisu,

- badane osoby wykorzystują portale społecznościowe do nawiazywania relacji nie tylko towarzyskich, ale również profesjonalnych. Stąd portale randkowe moga w przyszłości rozwijać się w strony budowania relacji szerszych niż tylko towarzyskie. Z drugiej strony istnieje już wiele portali, które realizują takie potrzeby (np. LinkedIn).

W związku z uzyskanymi wynikami można zakreślić kierunki dalszych prac, do których zaliczają się: analiza wykorzystania Facebooka do nawiązywania relacji towarzyskich (prawie wszyscy badani korzystaja $\mathrm{z}$ tego serwisu), jak również połączenie celów korzystania $\mathrm{z}$ serwisów randkowych z pełnym użytkowaniem danego serwisu (szczególnie Tinder czy Snapchat).

\section{Bibliografia}

Chmielarz, W. i Szumski, O. (2016b). Effects and impact of playing computer gamers on gamers. $\mathrm{W}$ : Communication, Management and Information Technology (s. 87-96). London: CRC Press Taylor\&Francis

Chmielarz, W. i Szumski, O. (2016a). Analiza wykorzystania gier komputerowych. W: Mobilne aspekty technologii informacyjnych (rozdz. 2.3, s. 65-80). Warszawa: Wydawnictwo Naukowe Wydziału Zarządzania UW.

Duggan, M. i Smith, A. (2014). Social media update 2013. Pozyskano z: http://pewinternet.org/ Reports/2013/Social-Media-Update.aspx.

Finkel, E.J., Eastwick, P.W., Karney, B.R., Reis, H.T. i Sprecher, S. (2012). Online dating: A critical analysis from the perspective of psychological science. Psychological Science in the Public Interest, 13 3-66. http://dx.doi.org/10.1177/1529100612436522.

Gatter, K. i Hodkinson, K. (2016). On the differences between Tinder versus online dating agencies: Questioning a myth. An exploratory study. 
Pozyskano z: https://www.researchgate.net/publication/299859003.

Greenwood, S., Perrin, A. i Duggan, M. (2016)

Facebook usage and engagement is on the rise, while adoption of other platforms holds steady. Pozyskano z: http://www.pewinternet.org/2016/11/11/socialmedia-update-2016/.

Internet World Stats (2016). Ilość użytkowników Internetu. Pozyskano z: http://www.internetworldstats.com/stats.htm.

Ritzer, G.F. (2014). The McDonaldization of Society, wyd. 8. Sage.

SingleboersenVergleich (2014). On the online dating market in Austria. Pozyskano z: http://www.singleboersenvergleich.at/presse/online-dating-marktstudieoesterreich-2013-2014.pdf.
Stownik jezyka polskiego PWN (2016). Serwis społecznościowy. Pozyskano z: http://sjp.pwn.pl/sjp/ serwis-spolecznosciowy;5579205.html.

Smith, A. i Anderson, M. (2016). 5 facts about online dating. Pozyskano z: http://www.pewresearch.org/ fact-tank/2016/02/29/5-facts-about-online-dating.

Szumski, O. (2008). Kulturalne uwarunkowania zawartości portali Web 2.0. W: J. Kisielnicki (red.), Inform@tyka dla przysztości (s. 300-310).Warszawa: Wydawnictwo Naukowe WZ UW.

Thompson, W.E. i Hickey, J.V. (2010). Society in Focus: An Introduction to Sociology.

Wesley, D. (2010). A Business of Love: Online Dating by The Numbers. Pozyskano z: https://www.creditloan.com/blog/a-business-of-love-online-datingby-the-numbers/. 